the coast is a remarkable series of raised beaches showing changes of the level of land and water, and indicating that the sea must at one time have stood at least 100 feet higher than at present. Photographs are reproduced in the volume to show the white gravels that cover these raised beaches on the west of Jura. There is also a fine view of pillow lavas associated with the black slate and limestones of the Loch Awe Group at An Aird. The concluding chapter contains an account of the mineral ores, glass sand, silicis bricks, building-stones, slates, and other economic products of the district.

\title{
VI.-BRIEF Notices.
}

1. Coals of the State of Washington. By F. Egghlston Surter. Bull. cccclxxiv of U.S. Geol. Surv., 1911. pp. 1-206, with 8 plates.

TNHIS memoir contains a full account of each coal-working in the 1 State of Washington, with geological sections and chemical analyses of the seams. There is also included an interesting detailed report of the methods of sampling, the chemical and physical properties of the coals, their impurities, and their uses.

2. The Recent and Fossic Jollosks of the ghes Alvania from the West Coast of America. By Padl Bartsch. No. 1863. From the Proceedings of the United States National Museum, vol. xli, pp. 333-62, with plates 29-32. Washington, 1911.

A VERY complete account of Gastropod shells of the genus Alvania $A$ is given in this paper. Eighteen new species are described, and two of these are found as fossils, and as fossils only, viz. A. pedroana and $\boldsymbol{A}$. fossilis, both from the Sand Rock at San Pedro, California. A history of research and a key to the genus precede the description of species. Most of the types of the new species were dredged by the United States Bureau of Fisheries steamer Albatross.

3. New Labyrinthodont fRom Kansas.-Labyrinthodonts are rare in the Coal-measures of North America, so the description of Erpetosuchus kansensis, Moodie, is especially welcome. The specimen consists of a fragment of a skull, two ribs, and the larger part of the left ramus of a mandible. These are preserved in the U.S. National Museum, and Mr. R. L. Moodie describes them in the Proceedings, rol. xxxix, pp. 489-95, 1911.

4. Water Divining and Radio-activitr.-Mr. Beeby Thompson has given an account of some experiments which showed conclusively that three reputed 'water diviners', without any real knowledge of what they were about, were affected by the presence of radium emanation (Journ. Northamptonshire Nat. Hist. Soc., xvi, September, 1911). Mr. Thompson is not conrinced that the diviners can be relied upon to find water, as in thirty-six records of their attempts in Northamptonshire, twenty were complete failures, and eight were virtual failures by reason of the fact that water was present everywhere below ground and one particular spot was no better than another. It is suggested that experiments be made on waters and rocks that are known to possess radio-active properties. 
5. Dingle Beds. - In a report on the 'Dingle Bed' rocks in the Dingle Peninsula, co. Kerry (Proc. Roy. Irish Acad., xxix, section B, No. 7, 1912) Mr. Alexander McHenry comes to the conclusion that the true position of the strata is below the Wenlock rocks, and that they are probably of Llandovery age.

6. Grpsem Deposits of Canada.-A report on the Gypsum deposits of the Maritime Provinces, Nova Scotia, New Brunswick, and the Magdalen Islands, has been prepared by Mr. W. F. Jennison (Department of Mines, Canada, 1911). The report shows by descriptions, maps, and photographs the vast extent of the deposits, the uses of gypsum, and the processes and cost of manufacturing it into a marketable product. The Canadian gypsum deposits are all regarded as forming part of the Lower Carboniferous. The origin of gypsum is discussed, and the distribution of the mineral in various parts of the world is giren.

7. Climatic Changes in Japan since the Pulocene Epoch.-This subject is discussed by Professor Matajiro Yokoyama (Journ. Coll. Sci. Tokyo, xxxii, art. 5, 1911). He concludes that the temperature in Central Japan has gradually increased since the earlier Pliocene, attaining its maximum in the Dilurial (Pleistocene), and then again decreasing to the present time. No evidence of glacial action has been met with in Japan.

\section{REPORTS AIND PROOEFDINGS.}

\section{Geological Societr of London.}

1. January 24, 1912.-Professor W. W. Watts, Sc.D., LL.D., M.Sc., F.R.S., President, in the Chair.

The following communication was read:-

"The Upper Keuper (or Arden) Sandstone Group and Associated Rocks of Warwickshire." By Charles Alfred Matley, D.Sc., F.G.S.

Under the name of the Arden Sandstone Group the author describes the strutigraphy of a sandstone zone in the Keuper Marls of Warwickshire, which is exceptionally well exposed in the area formerly occupied by the Forest of Arden.

This zone varies in lithological composition and thickness. It is nerer wholly a sandstone, but always contains beds of light-grey and pale-green shale, marl, and mudstone, which in places make up almost the whole of the zone. The sandstone, where present, usually forms thin, flaggy, white or light-grey beds, and exhibits ripple-marks, current-bedding, and surfaces with footprints and sun-cracks. The zone contains Estheria minuta; plants; teeth, spines, and scales of fishes; tracks and remains of labyrinthodonts and reptiles; and occasional casts of molluscan shells. The band is typically 20 to 25 feet thick, increasing sometimes to 40 feet or more; but it thins, especially eastwards and south-eastwards, to 4 or 5 feet.

The zone was first described by Murchison \& Strickland in 1837, but has not hitherto been completely mapped. The author traces 